\title{
Concept Territory of Lobo Architecture "Ngata Toro"
}

\author{
Fuad Zubaidi*, Happy Ratna Santosa, Muhammad Faqih \\ Department of Architecture Institute Technology of Sepuluh November (ITS), Surabaya, Indonesia \\ Email address: \\ fhoead@yahoo.co.id (F. Zubaidi), happyratna@yahoo.com (H. R. Santosa), faqih@arch.its.ac.id (M. Faqih)
}

\section{To cite this article:}

Fuad Zubaidi, Happy Ratna Santosa, Muhammad Faqih. Concept Territory of Lobo Architecture "Ngata Toro". Social Sciences. Vol. 3, No. 1, 2014, pp. 17-22. doi: 10.11648/j.ss.20140301.14

\begin{abstract}
Lobo is an architectural masterpiece that embodies the culture and have an important role in every activity and community interaction. Lobo as the embodiment of activities and indigenous communities, is a means of self-actualization in social interaction. In each community activities, "Lobo" has a role as a center of activity, and territoriality space eclectic emphasis on linkages between the human space. This study focuses on territory space Lobo architectural "Ngata Toro" as an behavior attribute of human interaction with the environment in which the occurrence of an activity. The method used in this study to conduct a literature study and mapping of behavior based on where in the course of community activities. The result is "Lobo" as a masterpiece of architecture and indigenous communities "Ngata Toro", has an important role as a community activity node, there is a space in the hierarchy concept of space as a territory marker function activities as well as stratification and social interaction. Lobo also has a function as a public space problem solving occurs.
\end{abstract}

Keywords: Territory, Lobo Architecture, Social Interaction, Ngata Toro

\section{Introduction}

The traditional architecture is an expression of culture and thought is the result of an afterthought relating to nature, God and man himself in his efforts to create an environment for accommodate settlements needs, working, or sociocultural.

The traditional architecture as one of the supporters of cultural identity, a phenomenon sediment and no escape from the process of cultural shift in a nation's, development is very slow so that the demands of the meaning of identity of traditional architecture is increasing. To avoid a shift in the value of the traditional architecture, the efforts needed guidance and development of Indonesian architecture, which emphasize the study of the cultural values associated with the traditional architecture is done in an integrated manner and understand the process of change [1].

Architecture 'Lobo' is meant as 'Stempel' is a building can not be separated from public life "Ngata Toro". 'Lobo' as well as the center of indigenous unity, governance and culture. 'Lobo' is a meeting hall and all activities associated with rural communities centered on the building. 'Lobo' also means building worship, ceremonies where traditional parties, a haven for people who are traveling and as a place of deliberation. Building 'Lobo' which has a function which is equipped with a versatile building 'Gampiri' or also called 'Buho' which not only serves as a granary but also as a place to receive distinguished guests.

Architecture 'Lobo' consists of three parts: head, body, legs, and is dominated by the roof because it covers almost the entire building at an angle of between $60-70^{\circ}$. The stage building structure as other traditional houses in Indonesia. Lobo architecture has two entrance is located opposite, in an open state because the building is not equipped with doors. "Lobo" as a masterpiece of architecture and indigenous communities "Ngata Toro", has an important role as a community activity node, in the space hierarchy have the concept of space territory, marker function activities as well as stratification and social interaction.

Haryadi [2], revealed that territory in environmental architecture and behavior is defined as the extent to which a living organism determine its demands, marking, and defend it, especially from the possibility of intervention from others. This concept was originally developed for nonhuman living organisms, but later used for human and environment concerns are also perceived imaginary environment.This means that for humans, the concept of territory over the demand for a local spatial and physical, but also emotional and cultural needs. The concept of territory in the architectural space "Lobo", shows the public perception of the existence of space and that space is very influential to the appropriate local culture. 


\section{Problem Statement}

The study contributes to the territorial space and cultural study of the behavior associated with the use and creation of spaces in a neighborhood setting. Cultural factors, environmental determinism approach to a traditional settlement emphasized that the shape and pattern are the natural consequences or response to the existing context.

The concept of territorial space in the context of traditional settlements still holding the culture and traditions are represented in the work of traditional architecture, need much studied. Lang [3], state "We have little understanding of the changes in patterns of territorial behavior of groups over time, although we do have some anecdotal information". Furthermore Lang [3], state "We have little understanding of how taste cultures have been structured and how they have changed over time". From the statement is very clear that the concept of territorial space still needs to be done in-depth studies to enrich the concept or theory of space.

Based on the above, the statement of the problem suggests the concept of territorial space study Architecture "Lobo" as a work of architecture is expected to enrich the development of concepts and theories in the study of territorial space architecture and environmental behavior.

\section{Theory Review}

\subsection{History and Development Lobo Architecture}

Was originally approximately \pm 500 years ago existing buildings in Kulawi only building used as a place of rest in the fields called "Toro wua" which leaves the base plugged directly into the ground as a shelter from the sun. Then evolved again into "Bamaru ncamali" ie shelter with 4 pole plugged into the ground and topped with leaves. Further into "Balawo" is a shelter with a form pole to the building stage but on a different floor with a pole to the roof, then sign the form "Bolanoa" with a transverse beam system. This is the fourth stage of the building "Lobo" was made as a customary deliberation, and then evolved again into "Pabuhu hampua" ie building with round columns construction system connected to a square pole and stands on a stone foundation.

"Pabuhu hampua" then became "Pabuhu dola" system of building construction with rounded poles standing on a rock, then evolved again into a "huma liongu Ari" is a building with a round pole construction system which stands directly on the ground, no longer uses as its foundation stone. In last appeared on stage called "Pabuhu dola hulapa opo" is the stage of building construction system with rectangular pole, then after that come in modern building construction.

\subsection{Form and Space Pattern of Lobo}

Lobo architecture shaped house on stilts, long rectangle, with the king pole in the middle, standing on wooden poles round which the average diameter $\pm 40 \mathrm{~cm}$, paved with rocks and reinforced with round wooden girder, Kaudern, [4] call it a 'temple'. The walls, pillars, beams buffer walls, floors, and roofs made of thick planks $\pm 10 \mathrm{~cm}$ and $\pm 40 \mathrm{~cm}$ wide, and then coated with some sort of roof shingle (board rather wide and slightly thicker) and both fibers on the surface of the roof and the ridge where the head is placed on the tip of the buffalo ridge. The entire construction do not use nails (iron), but still using the pegs, tongues system, and tied with a rope made of rattan poles at each meeting, walls, and floors.

Lobo made open architecture, $\pm 80 \mathrm{~cm}$ high walls, made without the room, the floor consists of 3 levels: the first level, is a rectangular room, the middle section is a pole king called 'Padence' is made of a circular beam where the heads results headhunting hanged man and to be adored with the traditional ceremony (now replaced with a buffalo head). This room is for common people, performing ritual dances and songs of worship, as well as take care of the need to eat and drink. The second floor as high as $\pm 60 \mathrm{~cm}$ of space made padence halls or also called 'Asari' located along or around the walls of the building, $\pm 150 \mathrm{~cm}$ wide on the right or left side of the room, reserved for the nobility, village authorities and stakeholders custom called 'Palangka I'. The third floor on the other side either side of the I Palangka high as $\pm 40 \mathrm{~cm}$ above the padence called 'Palangka II' is a special space reserved for distinguished guests from outside the village. On the front there Palangka 'Rapu' (kitchen) one or two pieces and made a seat on Rapu.

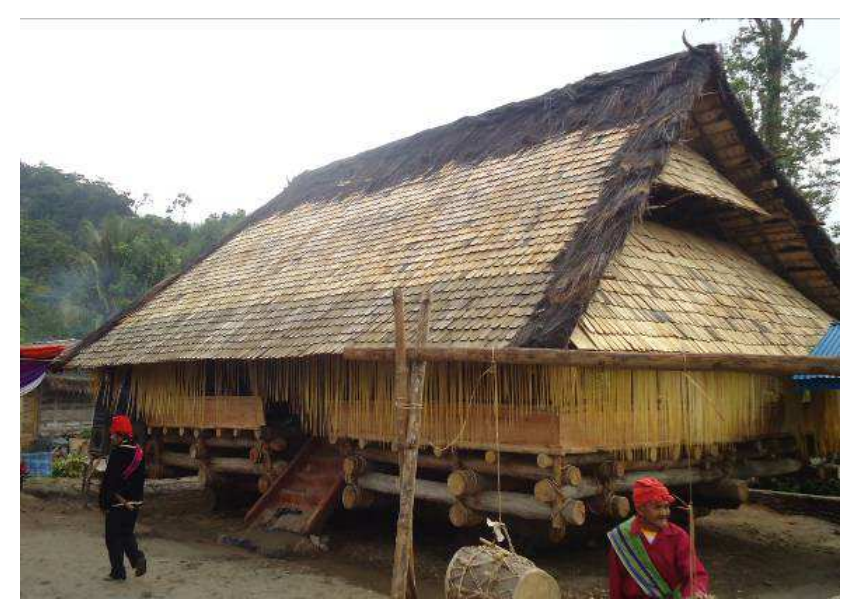

Figure 1. Architecture Lobo [5]

The entrance is rectangular, measuring $90 \times 120 \mathrm{~cm}$, with a thickness of $5 \mathrm{~cm}$ leaf doors. The door is usually located in the middle front side of the building, if there are two doors are always located opposite each other on either side of, and is located in front of the stairs. All poles should not be installed upside down, beam or girder shall lying transverse or counter-clockwise spin to the right (tip of the tree on the right), except for the bottom fastening rafters or at the end of the installed fastener from turning left as roof construction. 


\subsection{Concept of Territory}

Territorial behavior is a self-other boundary regulation mechanism that involves personalization of or marking a place or object and communication that it is owned by a person or group, [6]. As stated by Edney [6], depending on the type and degree of privacy in the context of cultural behavior patterns, in the personality and aspirations of the individual. The use of a wall, screen, limiting the symbolic and real barriers territory, is also a mechanism to demonstrate distance privacy environment in which the designer can control a variety of changes.

Altman [6], divides the territory into three categories associated with personal engagement, involvement, closeness to the everyday life of an individual or group and frequency of use. The three categories are primary, secondary and public territory. The three categories are very specific aspects related to the specific community culture.

When referring to the restrictions described above, the so-called private space is equivalent to a primary territory, while public place par with public territory. In line with Altman [6], Lyman and Scott [6], a classification that is comparable to the type of territoriality Altman, there are only two different types namely; territory interaction, and territorial bodies. Territory interaction aimed at areas that are temporal or instantaneous controlled by individuals or groups when performing interactions. Territory bounded by the human body.

Hussein El-Sharkawy 1979 in Lang [3], shows four types of territoriality that are useful in the design of the environment; Attached territory, Central territory, Supporting territory, and peripheral territory. Porteus [7], identifies the different things into three interrelated levels of territoriality, namely: personal space, home base (the spaces actively maintained), and home range (setting behavior formed part of one's life).

Brower [9], distinguishes the territory into four types; personal territory, territorial communities, society and territory free territory. The four types of these territories are classified based on: 1) the degree of control that made the use by others, 2) A person or group of persons take control, and 3) the presence of the signs that explain the controls. If one of these elements do not exist or are not effective, then the ability of the formation of the territory will decrease.

Ardrey [8], in the book "The Territorial Imperative", which states that there is a desire to maintain the area in animals and humans. Where in people's behavior as spacing mechanism that is always working procedures that take into account the meaning of space as the location and position or situation.

Haryadi [2], revealed that territory in environmental architecture and behavior is defined as the extent to which a living organism determine its demands, marking, and defend it, especially from the possibility of intervention from others. Lang [3], territoriality has four main characters, namely; ownership or rights from somewhere, Personalize or tagging of a particular area, the right to defend itself from outside interference, and control of multiple functions, ranging from meeting basic psychological needs up to satisfaction of the cognitive and aesthetic needs.

\subsection{Types and Functions of Territoriality}

From some of the definitions and scope of the theory of territory and territoriality, which is discussed and examined by several experts can be formulated: first, Territory as bounded space occupied; Pastalan [6], A territory is a delimited space that a person or group uses and defends as an exclusive preserve, Robert Sommer [10], Territory is visible, stationary, tends to be home centered, regulating who will interact. From the statement is obvious territory by the border of the space. The limit can be a wall, composition chair, table or symbolic laying of personal property. Second, Territory as the fulfillment of the needs of individuals or groups; Robert Sommer [6], A Territory is an area controlled by person, family or other face-to-face collectivity. Control is reflected in actual or potential possession rather than evidence of physical combat or aggression - at least at the human level. Robert Sommer emphasizes the sense of possession / ownership in terms of territory is more important than the desire to defend the territory from encroachment. Goffman 1963 [6], Territories are areas controlled on the basis of ownership and exclusiveness of use. 'This is Mine' or 'You keep off. Goffman looked at from the point of the usefulness of the concept of territory in self-actualization and status symbols (exclusiveness) while also asserts ownership. Altman and Haytorn [6], Territoriality involves in mutually exclusive use of areas and object by person or group. Altman and Haytorn [6] show that the territory occurred mutual relationship between the use of areas / places and objects around the person or group. In regard to the interests of the approach, the territory containing terms reduce complexity and make life easier in response to a variety of interests such as the regulation territory (the owner of the house has a rule on the other party guests also have their own rules in their respective positions). Third, Territory as a Real or Symbolic Sign; Pastalan [6], Territory involves psychological identification with a place, symbolized by attitudes of possessiveness and arrangements of objects in the area. Robert Sommer [6], Territorial are geographical areas that are personalized or marked in some way. Research conducted by Altman, Nelson and Lett, [6] in a study of family life, it was found that those who sleep in the same room with the territorial marking symbols such as the placement of the bed, color pillow-bolsters, bedspreads distinguish from each other. Along with that is when they are at the dining table, dining chair shows territorial arrangement and each implies recognition of ownership of the chair at the time. They are relatively still choose the chair as seating and rarely meaningful change. Fourth, Territory as a maintained ownership of space; Sommer and Becker [6], Territorial are defended from encroachment. 
(Lyman and Scott, in Altman) [6], Territorially involves the attempt to control space. Encroachment can take the form of violation, invasion, or contamination and defensive reaction can involve turf defense, insulation or linguistic collusion. Lyman and Scott [6] even further to explain the possibility of violations of the territorial (which cause taste disturbance) also revealed the possible repercussions on the disorder. Thus the territory has elements' desire to retain ownership. Fifth, Territory satisfy some need or encouragement like status; Robert Sommer, [6], A Territory is an area controlled by person, family or other face-to-face collectivity. Control is reflected in actual or potential possession rather than evidence of physical combat or aggression - at least at the human level. Altman and Haytorn [6], Territoriality involves in mutually exclusive use of areas and object by person or group. These things show that the territory occurred mutual relationship between the use of areas / places and objects around the person or group. Territory also controls the input of the world outside the territory such as the use of the board "Do not look around here" will make clear boundaries and make territorial identity.

\section{Result and Discussion}

\subsection{Development of Lobo Architecture}

Architecture Lobo has a fairly complex function, namely as a place of deliberation and implementation of traditional ceremonies (such as salvation, thanksgiving, distanced disasters and disease, the great guest welcome, welcome or removing soldiers will fight, and will Tadulako and from the battlefield ), establish village rules, adjudicate matters customs violations and other crimes, and discuss the issue of agriculture and rural economy. In addition Lobo also serves as a residence or a king 'Tuana Mahila' (who was sick), but as a place to conduct activities related to the village, so that the building is set up near or next to the Village Hall. It is meant when there is activity to be carried out easily achieve all levels of society, so the architecture Lobo has a large yard. Lobo as the open architecture of the building has no ventilation, natural light wall so easy to get into the building.

In this type, pattern and hierarchy of space is not very clear, that is limiting the space allotment. In contrast to the buildings that were in the valley Kulawi, and the pattern is still clear hierarchy, where the public was on the ground floor, while the village stakeholders, elders, and others were on the top floor, as a form of homage to the more respected or elder.

Change does not occur in a building that functions as a place of deliberation, assemble and perform traditional feast. With respect to function, generally lobo village lies on the main road so that people can easily reach it if there are events or indigenous parties.

\subsection{Lobo Function}

Lobo architecture in the past have not been exposed to outside influences, namely the introduction of Islam and Christianity, is a building that can not be separated from public life. Lobo in the reign of the kings is the center of unity indigenous, culture and government.

The nobles (maradika) as the holder of the reins of government, indigenous experts and scholars important people in the building to hold meetings to discuss issues relating to:

a. Formulation of laws, indigenous regulations;

b. Implementation of the government, in terms of dispatch and receiving of the army;

c. Termination / adjudicate matters on any violations, fraud and crime. The carrying out of punishment can be implemented in Lobo or elsewhere, for example in a tree in the woods or on the edges of time, according to the type and variety acts;

d. In matters relating to the economy: when did start opening gardens, fields; begins when planting, reaping, waters and other settings;

e. In addition to these things, Lobo also the implementation of indigenous parties, in connection with:

1) Safety villages, in order to avoid a wide variety of infectious diseases, disaster and curse the gods as a result of perversity indigenous law.

2) Thanksgiving in connection with a good harvest.

3) Welcome / dispatch troops war

4) Welcoming the distinguished guests from outside the area and so forth.

\subsection{Space Territory of Lobo Architecture "Ngata Toro"}

Lobo architectures "Ngata Toro", has its own pattern and hierarchy of spaces, in accordance with the requirements of the time. Currently Lobo architecture changes, especially in the pattern space. The space is no longer making Lobo levels as the original, but the area to be occupied by indigenous stakeholders, government officials, or ordinary citizens are still valid. For example: Asari is where the village officials, village elders Indigenous Stakeholders.

Indigenous Elders, Elders Rural Stakeholder village or conducting usually sit at the front of the right, if the event was a village meeting or prosecute an offense they will be in the middle and surrounded by other people on the sides of the building.

Hierarchical pattern Lobo architectural space has been arranged in such a way in accordance with versatile functions. The floor consists of three levels, the center of the room is rectangular-shaped with a king pole in the middle called "padence", is for ordinary people to sit, a place set meal / drink, and a place to dance and sing.

Left and right doors contiguous section shaped like a stage / halls $( \pm 60 \mathrm{~cm}$ above padence) is specifically reserved for the nobility of government and indigenous stakeholders, this room is called "Palangka". No longer the 
side of contiguous Palangka height $\pm 40 \mathrm{~cm}$ above padence reserved for guests from out of town who are considered respectable. Lobo overall building area is $1100 \times 765 \mathrm{~cm}$, with a floor area of $660 \times 520 \mathrm{~cm}$. One thing that is important to note that not all of society allowed to enter in Lobo, except in certain things that are considered very important. Thus Lobo is not building a social function in general but rather the Sacred, and even by some people considered sacred buildings, the great and holy. It is fitting that the Swedish researchers, Kaudern [4] have called "temple".

Lobo has a simple form, but it is quite unique. Modern tools has not been too much interference in the manufacturing process. Belandar poles of the original round timber from the forest, outer skin peeled and then mashed with a machete. The round wooden average diameter of $40 \mathrm{~cm}$.

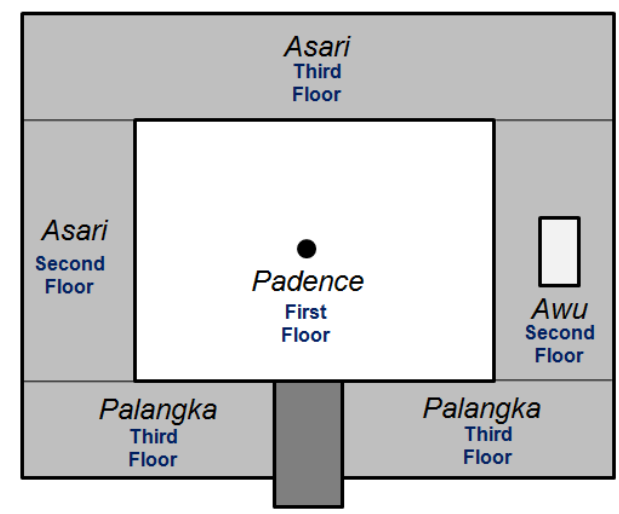

Figure 2. Space Patern Architecture Lobo [5]

If you look at the pattern of architectural space Lobo hierarchy related how behavior and culture "Ngata Toro", the division of space social stratification based on how the existing community and using the building Lobo. Spaces are limited formed a territory set up a space structure that is based on the function space; bounded space occupied, as the fulfillment of the needs of society, as a sign sebua real / symbolic, and the fulfillment of social status boost.

Based on the concept of territory by Altman [6], which divides the territory into three categories: primary, secondary and territory public, it can be concluded that the Lobo architectures "Ngata Toro", type of territory are formed based on the existing functions that need a boost in social status, as a sign of real and symbolic and bounded space inhabited. If you look at the pattern of territorial space, there is a territory that has a dual ownership in architecture "Lobo" is space that is parallel to the space "Palangka" equal height with room for guests, but higher than a "Padence". This space can double when there is activity in the building Lobo is not an activity that is very sacred or very special.

At village meetings or activities prosecute a violation of the sides of the room used for the stakeholders and elders / village.

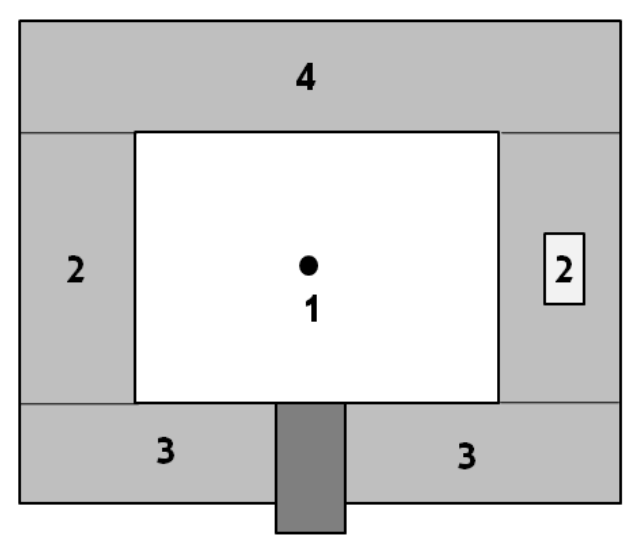

Figure 3. Space Territory Architecture Lobo [5]

Pictured above explained patterns of territorial space in architecture Lobo,

1. Central room or space that is commonly called "padence" as the territory of public use and can be entered by anyone but he must comply with the existing norms, this space is used for the general public and is also commonly used to prosecute people who commit violations.

2. Space side of the building there is also a "Avu" or small kitchen or also intended to guests as a secondary territory, a space or area that is not too exclusively by a person or group of people with coverage area relatively wider and controlled or regularly controlled.

3. Space side of the stairs or referred to as a "Palangka", as a primary territory is used specifically for elders and indigenous stakeholders. An area used exclusively, realized by others, and controlled permanently and became a major part in the activities there.

4. Parallel space of "Palangka" as indigenous territory can be used for two functions, namely territory or territorial public secondary territories controlled by function activities that take place.

\subsection{Space Territory of Lobo as Behavior Atribute and Culture}

The concept of territory in the study of architectural space environment and the behavior that is the demand of people over an area to meet the physical, emotional and cultural. This relates to the emotional needs of the territory concept associated with private space and public space. This concept was originally developed for nonhuman living organisms, but later used for human and environment concerns are also perceived imaginary environment. That is the human concept of territory over the demand for a spatial and physical space, but also emotional and cultural needs.

The concept of territory is inseparable with regard ba-how relationships that occur within a territory or commonly referred to as territoriality.Territoriality is an attribute behavior by Weissman [11], an analysis of the attributes that describe the relationship between an individual (including a collection of individuals who form a 
group or group), and the institution or organization in a system that involves the interaction of a space or set of activities. In the behavioral attributes, there are three interacting components, namely individual, institution or organization, and the physical setting or environment. Territoriality is closely related to human behavior toward the environment, Weissman [11], categories of territoriality as one of the attributes of behavior in which there is a relationship between individuals, groups / organizations with the physical setting.

While the physical setting as described by Rapoport [12], has a physical element and activities. From some of these opinions, it can be concluded that the territoriality there are three main elements contained in it is physical setting (territory), actors (individual / group), and a variety of activities.

As mentioned above, territoriality space as attributes of behavior can't be separated from the influence of the culture that exists in an environmental setting, it is supported by what is described Haryadi [2], in the context of the environment can't be separated from the factors that influence; factors religious, behavioral, and cultural factors

\section{Conclusion}

Lobo is the architecture of the building reflects the cultural values that typify the characteristics society cultures. Lobo traditional architecture is one of the traditional building assets in Central Sulawesi are specific and unique, reflecting cultural values (religion and belief) that develops in the community, especially "Ngata Toro" which is expected to be preserved and protected from extinction. One of the traits or characteristics of interest are patterns that reflect the uniqueness of territorial behavior and culture "Ngata Toro".

Although the shape has changed but the function of the building as the building Lobo perform traditional ceremonies have not changed, so that the values Lobo architecture should also not change according to the values that develop in communities in the valley in particular and society Kulawi who inhabit the valley (Lore , Behoa, Bada,
Kulawi, etc.) Central Sulawesi in general.

Lobo Architecture is a building that functioned as the center of indigenous unity, or as a customary deliberation, concerning such things as the formulation of laws, government enforcement, court case, the economy, and traditional ceremonies. Lobo architecture is a reflection of the fabric of togetherness previous ones, which must be maintained and preserved

\section{References}

[1] Budiharjo. Eko, Arsitektur Indonesia dalam Perspektif Budaya, PT Alumni, Bandung.(2009)

[2] Haryadi, Setiawan. B, Arsitektur Lingkungan dan Perilaku, Proyek Pengembangan Pusat studi Dirjen Dikbud. Yogyakarta.(1995)

[3] Lang, J., Creating Architectural Theory: the Role of the Behavioral Sciences in Environmental Design. New York: Van Norstrand Reinhold.(1987)

[4] Kaudern, Walter, Structures and Settlements in Celebes. Result of the Author's Expedition to Celebes 1917-1920.(1922)

[5] Zubaidi.Fuad, Upacara "Pompede Lobo" Ngata Toro. (2013)

[6] Altman, I, The Environment and Social Behavior. Monterey, CA: Wadsworth. (1975)

[7] Porteous.J. Douglas, Environment And Behavior, Addison Wesley Publishing Company, England. (1977)

[8] Ardrey, R, The Territorial Imperative", New York, Atheneum.(1970)

[9] Brower, S.N., Territory in Urban Settings. in Altman, (1980), Human Behavior and Environment. Plenary Press, NY and London.(1976)

[10] Sommer. Robert, Social Design: Creating Building with People in Mind, Prentice-Hall Inc, New Jersey.(1983)

[11] Weissman, Gerald, D, Modeling Environmental Behavior System, A Brief Nose, Journal of Man Environment Relation, Vol. 1. No. 2 The Pennsylvania State University. (1981)

[12] Rapoport, A, Human Aspect of Urban Form, Pergamon Press, New York. (1977) 